\title{
THE RELATIONSHIP BETWEEN GENDER, HISTORY OF ANKLE SPRAIN, AND ANKLE STABILITY WITH ANKLE SPRAIN STATUS
}

\author{
Zhafira Faruhasa \\ Epidemiology Department, Faculty of Public Health, Airlangga University. Surabaya, Indonesia \\ Correspondence Address: Zhafira Faruhasa \\ Email: zhafira.faruhasa-2015@fkm.unair.ac.id
}

\begin{abstract}
Injuries can occur as a result of various activities, which of them is a sport. In 2017, basketball was a sport that produced the highest prevalence of injury incidence in the United States at $15.77 \%$. Athletes who have ankle sprain are $20-40 \%$ more likely to experience chronic ankle instability. This study analyzed the relationship between gender, history of ankle sprain, and ankle stability with ankle sprain status in basketball athletes of Universitas Airlangga Surabaya. This study was analytical-observational research using a cross-sectional design. The research population was basketball athletes who were members of the basketball club of Universitas Airlangga, and finally there were 23 respondents selected as the research samples. The sample selection used the accidental sampling technique. The results of chi-square test $(\alpha=0.05)$ indicate that there was a relationship between the previous history of ankle sprain $(\mathrm{p}=0.002 ; \mathrm{RR}=9.1)$ and ankle stability with ankle sprain status $(\mathrm{p}$ $=0.013 ; \mathrm{RR}=6$.), but gender had no relationship with ankle sprain status $(\mathrm{p}=0.435 ; \mathrm{RR}=1.6)$. It concludes that the history of ankle sprain injury and ankle stability were related to ankle sprain status, but gender was not related to it.
\end{abstract}

Keywords: gender, history of ankle sprain, ankle stability, ankle sprain

\begin{abstract}
ABSTRAK
Cedera dapat terjadi akibat dari berbagai aktivitas manusia, salah satunya adalah olahraga. Pada tahun 2017, Bola basket merupakan olahraga yang menghasilkan kejadian cedera tertinggi di Amerika Serikat dengan prevalensi sebesar 15,77\%. Atlet yang mengalami pergelangan kaki terkilir memiliki kemungkinan sebesar 20$40 \%$ untuk mengalami ketidakstabilan pergelangan kaki kronis. Penelitian ini bertujuan untuk mengetahui hubungan antara jenis kelamin, riwayat pergelangan kaki terkilir dan stabilitas pergelangan kaki dengan kejadian pergelangan kaki terkilir pada atlet bola basket Universitas Airlangga Surabaya. Jenis penelitian ini merupakan penelitian observasional analitik dengan desain potong lintang. Populasi penelitian adalah atlet bola basket yang tergabung dalam Unit Kegiatan Mahasiswa (UKM) Bola Basket Universitas Airlangga Surabaya, dan terdapat 23 responden terpilih sebagai sampel. Pemilihan sampel menggunakan teknik sampling aksidental. Hasil uji chi-square $(\alpha=0,05)$ menunjukkan bahwa terdapat hubungan antara riwayat pergelangan kaki terkilir sebelumnya $(p=0,002 ; R R=9,1)$ dan stabilitas pergelangan kaki $(p=0,013$ dan $R R=6,4)$ dengan kejadian pergelangan kaki terkilir, sedangkan jenis kelamin tidak berhubungan dengan kejadian pergelangan kaki terkilir $(p=0,435 ; R R=1,6)$. Dapat disimpulkan terdapat hubungan antara riwayat pergelangan kaki terkilir sebelumnya dan stabilitas pergelangan kaki terkilir dengan kejadian pergelangan kaki terkilir, sedangkan tidak terdapat hubungan antara jenis kelamin dengan kejadian pergelangan kaki terkilir.
\end{abstract}

Kata kunci: jenis kelamin, riwayat pergelangan kaki, stabilitas pergelangan kaki, pergelangan kaki terkilir.

\section{INTRODUCTION}

Injury is an incident caused by various activities, one of which is sports. Sport is an activity performed with conscious regular movements to increase body functions. Human do sports because of achievement, recreation, health, and education (Giriwijoyo, 2017).
The national proportion of injuries in sports was 3.5\%. East Java province has the same high proportion of sport injuries as the national proportion (Indonesian Ministry of Health, 2013). Sports injuries can be caused by two factors: intrinsic factors and extrinsic factors. Intrinsic factors include the athlete's condition, such as tissue structure, tissue weakness, body posture, activity level, lack of physical and 
mental readiness, while extrinsic factors include sport activities, such as sports equipment, falls or exposure, and training methods (Indonesian Ministy of Youth and Sports, 2015).

Sprains, strains, knee injuries, Achilles tendon injuries, pain along the shin, fractures, and dislocations are the most common types of injuries in sports (National Institute of Arthritis and Musculoskeletal and Skin Disease, 2004). Based on Fong et al., (2007), ankle sprain was the most common type of injury in the Netherlands (73\%), the United States $(68.3 \%)$, and Hong Kong (33\%). It is estimated that about 3,140,132 ankle sprain injuries in the United States have occurred to $1,461,379,599$ people/year with an incidence rate of 2.15 per 1,000 people/year (Waterman et al., 2010). The sprain was the fourth-highest type of injury in Indonesia in 2007 with a prevalence of $20.9 \%$ (Indonesian Ministry of Health, 2007). In 2013, the incidence of sprain increased to become the secondlargest type of injury in Indonesia with a proportion of $27.5 \%$ (Indonesian Ministry of Health, 2013).

The highest incidence of ankle sprain was found in team sports and field matches, for example basketball (Fong et al., 2007). About half of all ankle sprain incidents occurred due to athletic and basketball activities (41.1\%) (Waterman et al., 2010).

The high prevalence of ankle sprain in basketball can largely be attributed to the nature of the sport which involves rapid changes in direction, player contact, repetitive jumps, and landing activities. Research conducted by Tummala et al., (2018) shows that basketball players changed movements every 2.0 to 2.82 seconds and jumped up from 35 to 46 times per game. Basketball is considered a limited-contact sport. Running with explosive movements and changes in direction and fast speed is part of the basketball features. Extreme pressure on the body during play has the potential to cause injury. Ankle sprain can occur to atheletes when they are practicing, competing, or after competing (O'Connor et al., 2004).

Further, Gordon et al., (2014) researched WNBA athletes (Women's National Basketball Association) and NCAA (National Collegiate Athletic Association) in the United States. They have shown that 117 of 172 athletes $(69.11 \%)$ reported having ankle sprain. Another study conducted by Ito et al., (2015) shows that the most common injuries in Japanese basketball athletes were legs and ankle sprain $(24.8 \%$ in men and $23.8 \%$ in women). This study finds the highest proportion of ankle sprain occurred to the atheletes $(58 \%$ in men and $64.4 \%$ in women). In 2017, basketball resulted in the highest number of injuries in the United States with the prevalence of $15.77 \%$ (Consumer Product Safety Commission, 2017).

According to Sarwack and Chyntia (2014), athletes who experience ankle sprain have a $20-40 \%$ chance of experiencing chronic ankle instability. Ankle sprain can also cause a continuum of lifelong consequences such as disability and decreased quality of life (Wikstrom, et al., 2013). These long-term consequences include changes in gait, disability to withstand loads, and maintain a stable support base (Hoch et al., 2016).

To begin the research, this study aimed to determine the relationship between gender, history of ankle sprain, and ankle stability with ankle sprain status in basketball athletes at Universitas Airlangga, Surabaya.

\section{METHODS}

This study was an analyticalobservational study using a cross-sectional research design. The population in this study was basketball athletes who were members of the basketball club at Universitas Airlangga Surabaya. Of the population, the sample was 23 respondents 
selected using the accidental sampling technique. This study was conducted in March 2019 at GOR CAMPUS C Universitas Airlangga, Surabaya. The research dependent variable was ankle sprain status, while the independent variables were gender, history of ankle sprain, and ankle stability.

The history of ankle sprain were injuries that the respondents experienced in the last 6 months since the study was conducted. In the questionnaire, it asked whether the respondents had ever or never the ankle sprain. Ankle stability was measured using a balance test so-callled a single-leg stance test, where the respondents stood one foot with knees bent at an angle of $90^{\circ}$ forward, arms straight to the sides, and eyes open for 30 seconds. This test was carried out to both legs alternately. The test results were considered positive if the athletes were unable to test one or both legs (Trojian and McKeag, 2006). Ankle stability was categorized into 2 categories: good (if the test results were negative) and bad (if the test results were positive).

Data on ankle sprain were obtained from the scale results of the Foot and Ankle Measure (FAAM). The FAAM was an instrument that describes functional limitations for ankle and foot disorders. The FAAM consisted of 29 questions divided into 2 measurements: 21 questions for daily activity measurement and 8 questions for sports measurement. Sports measurement was used to investigate athletes or populations with high physical activities (Martin, 2003). Therefore, this study only used the sport measurement. The total scores of this measurement ranged from 0 to 32 . The sum of the scores from all answers was then added up and divided by the largest possible value. It was then multiplied by 100 to get a percentage. The higher score obtained indicated better functional quality. Ankle sprain status was categorized into two: injury (FAAM score of more than $75 \%$ ) and non-injury (FAAM score of less than $75 \%)$.

Data were analyzed using bivariate and multivariate analyses. Bivariate analysis could determine the distribution of variables in the form of cross-tabulation using a computer application, while multivariate analysis could identify the relationship between the dependent variable and the independent variables using the chi-square test with a $\alpha$-value of 0.05 . This study has obtained an ethical approval from the Ethics Commission of Faculty of Public Health Airlangga University No: 63/EA/KEPK/2019.

\section{RESULTS}

\section{The distribution of respondents' characteristics by gender}

The results show that the majority of respondents were female as many as 14 people $(51.9 \%)$, while there were only 9 male respondents $(39.1 \%)$ (Table 1$)$.

Table 1. The Distribution of Respondents's Characteristics by Gender.

\begin{tabular}{lcc}
\hline Gender & $\begin{array}{c}\text { Freque } \\
\text { ncy }\end{array}$ & $\begin{array}{c}\text { Pecentage } \\
(\boldsymbol{\%})\end{array}$ \\
\hline Male & 9 & 39.1 \\
Female & 14 & 51.9 \\
\hline Total & 23 & 100 \\
\hline
\end{tabular}

The distribution of respondents' characteristics by history of ankle sprain

Table 2. The Distribution of Respondents' Characteristics by History of Ankle Sprain.

\begin{tabular}{lcc}
\hline $\begin{array}{c}\text { History of } \\
\text { Ankle Sprain }\end{array}$ & $\begin{array}{c}\text { Freque } \\
\text { ncy }\end{array}$ & $\begin{array}{c}\text { Percentage } \\
(\boldsymbol{\%})\end{array}$ \\
\hline Ever & 10 & 43.5 \\
Never & 13 & 56.5 \\
\hline Total & 23 & 100 \\
\hline
\end{tabular}

The results indicate that 10 respondents who had suffered from ankle 
sprain $(43.5 \%)$, while 13 respondents had no history of ankle sprain $(56.5 \%)$ (Table 2).

\section{The distribution of respondents' characteristics by ankle stability}

This study finds that 12 respondents had good ankle stability (52.2\%), while and 11 respondents had poor ankle stability (47.8\%) (Table 3 ).

Table 3. The Distribution of Respondents' Characteristics by Ankle Stability.

\begin{tabular}{lcc}
\hline $\begin{array}{c}\text { Ankle } \\
\text { Stability }\end{array}$ & $\begin{array}{c}\text { Freque } \\
\text { ncy }\end{array}$ & $\begin{array}{c}\text { Percentage } \\
(\boldsymbol{\%})\end{array}$ \\
\hline Good & 11 & 47.8 \\
Bad & 12 & 52.2 \\
\hline Total & 23 & 100 \\
\hline
\end{tabular}

Ankle sprain status

The results show that only 8 respondents had ankle sprain (34.8\%), while the others did not suffer from ankle sprain (65.2\%) (Table 4)

Table 4. The Distribution of Ankle Sprain Status among Basketball Athletes.

\begin{tabular}{lcc}
\hline $\begin{array}{c}\text { Ankle Sprain } \\
\text { Status }\end{array}$ & $\begin{array}{c}\text { Freque } \\
\text { ncy }\end{array}$ & $\begin{array}{c}\text { Percentage } \\
(\boldsymbol{\%})\end{array}$ \\
\hline Injury & 8 & 34.8 \\
Non-Injury & 15 & 65.2 \\
\hline Total & 23 & 100 \\
\hline
\end{tabular}

The relationship between gender and ankle sprain status
Table 5 shows that the majority of respondents were women, but the prevalence of ankle sprain status was greater in men $(44.4 \%)$ than women $(28.6 \%)$ despite the same number of people with injuries in both men and women. The chi-square test finds no relationship between gender and ankle sprain status with a p-value of 0.435 and an RR value of 1.6, meaning male athletes had a 1.6 times greater risk for ankle sprain than women.

The relationship between history of ankle sprain and ankle sprain

This study points out the most respondents with ankle sprain status had ever a history of ankle sprain beforehand $(70 \%)$. It finds a relationship between a history of injury and ankle sprain status with a p-value of 0.002 and a RR value of 9.1, meaning those with a history of ankle sprain had a 9 times greater risk for ankle sprain than those who never had such history.

\section{The relationship between ankle stability and ankle sprain status}

In this study, most ankle sprain occurred in basketball athletes who had poor ankle stability (58.3\%). The chisquare test reveals ankle stability had a relationship with ankle sprain status with a p-value of 0.013 and an RR value of 6.4, indicating athletes with poor ankle stability were 6 times more likely to suffer from ankle sprain injuries than those with good ankle stability.

Table 5. Analysis of the Relationship between Gender, History of Ankle Sprain and Ankle Stability with Ankle Sprain Status.

\begin{tabular}{|c|c|c|c|c|c|c|c|c|}
\hline \multirow{3}{*}{ Variable } & \multicolumn{4}{|c|}{ Ankle Sprain Status } & \multirow{2}{*}{\multicolumn{2}{|c|}{ Total }} & \multirow{3}{*}{$p$} & \multirow{3}{*}{$\mathbf{R R}$} \\
\hline & \multicolumn{2}{|c|}{ Yes } & \multicolumn{2}{|c|}{ No } & & & & \\
\hline & $\mathbf{n}$ & $\%$ & $\mathbf{n}$ & $\%$ & $\mathrm{n}$ & $\%$ & & \\
\hline \multicolumn{9}{|l|}{ Gender } \\
\hline Male & 4 & 44.4 & 5 & 55.6 & 9 & 39.1 & 0.435 & 1.6 \\
\hline Female & 4 & 28.6 & 10 & 71.4 & 14 & 60.9 & & \\
\hline Injury History & & & & & & & & \\
\hline
\end{tabular}




\begin{tabular}{|c|c|c|c|c|c|c|c|c|}
\hline \multirow{3}{*}{ Variable } & \multicolumn{4}{|c|}{ Ankle Sprain Status } & \multirow{2}{*}{\multicolumn{2}{|c|}{ Total }} & \multirow{3}{*}{$p$} & \multirow{3}{*}{$\mathbf{R R}$} \\
\hline & \multicolumn{2}{|c|}{ Yes } & \multicolumn{2}{|c|}{ No } & & & & \\
\hline & $\mathbf{n}$ & $\%$ & $\mathbf{n}$ & $\%$ & $\mathbf{n}$ & $\%$ & & \\
\hline Ever & 7 & 70 & 3 & 30 & 10 & 43.5 & 0.002 & 9.1 \\
\hline Never & 1 & 7.7 & 12 & 92.3 & 13 & 56.5 & & \\
\hline \multicolumn{9}{|l|}{ Ankle Stability } \\
\hline Good & 1 & 9.1 & 10 & 90.9 & 11 & 47.8 & 0.013 & 6.4 \\
\hline Poor & 7 & 58.3 & 5 & 41.7 & 12 & 52.2 & & \\
\hline Total & 8 & 34.8 & 15 & 65.2 & 23 & 100 & & \\
\hline
\end{tabular}

\section{DISCUSSION}

\section{Respondents' Characteristics}

The respondents in this study were dominated by females. In today's modern era, basketball game has developed. More and more people are fond of basketball. In Indonesia, basketball is a sport that has become a trendsetter in several circles, ranging from the groups with the lowest to the highest educational levels. Although basketball is generally a popular sport for men, it is currently played by many women in all ages and body sizes (Sitepu, 2018).

Analyzed from the the history of ankle sprain, fewer respondents had experienced ankle sprain during the last six months since the study was conducted. The distribution of respondents' characteristics by ankle stability proves that the majority of respondents had poor ankle stability. Another previous study shows men had fewer inversion weaknesses but greater postural dynamic control compared to women (Ericksen and Gribble, 2012).

Based on the results of this present study, only a few respondents had ankle sprain status. Some athletes had probably been recovered when the study was conducted. With proper care, someone with ankle sprain can resume their daily activities after a certain period (Haddad, 2016).

\section{The relationship between gender and ankle sprain status}

The results indicate that men had a greater percentage of ankle sprain status. It is in line with research conducted by Bruene (2014) which shows that male athletes aged 15-24 had higher incidence of ankle sprain than women in the same age group. In other words, gender did not have a significant relationship with ankle sprain status.

Similarly, this recent study figures out that there was no significant relationship between gender and ankle sprain status. Male athletes were 1.6 times more likely to sufer from ankle sprain than women. Ching Yee (2016) finds similar findings, which state there was no significant relationship between gender and ankle sprain status ( $\mathrm{p}=0.443)$, and men had higher incidence of ankle sprain $(60.3 \%)$ than women $(54.0 \%)$.

Waterman et al., (2010) had different points of view. They claim gender affected the incidence of ankle sprain, and higher risk of having ankle sprain occurred mostly to women over 30 years than men in that age group regardless of their body mass index. Supporting Waternman's study, Tummala et al., (2018) find that women had more ankle sprain incidence than men. This could be due to differences in playing styles between men and women, as well as differences in the strength of ligaments, hormones, height, weight, and energy metabolism.

Some factors that have contributed to the higher incidence of injury in female athletes include higher estrogen levels, less muscle mass, and more body fat. Besides, hormonal changes during the menstrual cycle also make women very vulnerable to 
injury (Shmerling, 2015). Overall, the distribution of ankle sprain incidence was relatively similar between men and women (Tummala et al., 2018). Gender is an intrinsic factor often associated with the incidence of ankle sprain (Ericksen and Gribble, 2012).

\section{The relationship between history of ankle sprain and ankle sprain}

The results find a significant relationship between a history of ankle sprain and ankle sprain status. Athletes who had ever experienced ankle sprain beforehand had a 9 times greater risk of having ankle sprain again than those who never experienced ankle sprain. The results of this study are in line with two previous studies conducted by McKay et al., (2001) and Baumbach et al., (2013). McKay et al., (2001) state that a history of ankle sprain was the strongest risk factor for the second ankle sprain and so forth. Athletes with previous ankle sprain were 5 times more likely to get recurrent injuries than athletes with no injury beforehand. Baumbach et al., (2013) assert that a history of previous ankle sprain injuries was a major risk factor for ankle injuries, but the relationship between history of injuries and injury status was only significant in male athletes.

There was increased risk of a lateral ankle ligament injury in athletes who had previously experienced the same kind of injury. The condition of the joint in post injuries, damage, and injury treatment may contribute to this finding (Beynnon, Murphy and Alosa, 2002). It is estimated that $30 \%$ of people with ankle sprain would develop chronic instability in the ankle joint (Chinn and Hertel, 2010).

Walden, et al. (2005) state that $15 \%$ of all ankle sprain incidents were recurrent injuries. Furthermore, Sankey et al. (2008) discover $27 \%$ of all ankle sprain incidents were recurrent injuries. Ankle sprain should not be ignored, and thus taking proper care and rehabilitation can result in good recovery; otherwise, it will cause permanent pain and even worse long-term effects, such as chronic ankle pain, ongoing instability, articular degeneration of the talus, and increased risk of osteoarthritis (Haddad, 2016). Recurring pain can cause the ankles to experience mechanical and functional instability simultaneously Mechanical instability is characterized by limited ankle motion or complex structural abnormalities in the ankle. Whereas functional instability is the state of subjective feelings on the ankles in performing physical activities or simple daily routines. Mechanical and functional instability rarely occurs simultaneously but sequentially. (Peterson and Renstrom, 2005).

Ankle sprain that lasts for a long period and does not get the right treatment can lead to disability. For example, people with such injury will lack ability to carry out normal bodily movements and activities (Barr and Harrast, 2005).

Around $80 \%$ of acute ankle sprain incidents may be healed with therapy, but $20 \%$ will develop into mechanical or functional ankle instability resulting in chronic ankle instability. Chronic ankle instability causes earlier degenerative changes in the ankles due to unbalanced loads on the medial side of the ankles (Chan, Ding and Mroczek, 2011). Patients with chronic ankle instability usually complain of persistent pain, recurrent sprain, and repeated episodes of the giving out ankles. In some cases, there are also symptoms of persistent tendinitis or synovitis, stiff ankles, swelling, pain, and muscle weakness.

\section{The relationship between ankle stability and ankle sprain status}

The results of this study indicate that ankle stability had a significant relationship with ankle sprain status. Athletes who had poor ankle stability were 6 times at more risk of having ankle sprain compared to those with good ankle stability. The results are in line with research conducted by Mann and Meir 
(2002) which say that someone who had poor balance was 7 times more likely to suffer from ankle sprain. Similarly, Kobayashi, Masashi and Masahiro (2016) and Halabchi et al., (2016) discover a significant relationship between stability and ankle sprain incidence. The positive single-leg balance test shows ankle stability had a significant relationship with the incidence of ankle sprain $(\mathrm{p}=0.016)$ (Trojian and McKeag, 2006). McHugh et al., (2006) state different result which says balance was not a significant risk factor for ankle sprain.

Most respondents who experienced Chronic Ankle Instability (CAI) had a poor balance condition. Impaired ankle stability $=$ results in slower activation of ankles, knees, and hip muscles compared to normal stability (Deun, et al.2007). Feger and Luke (2014) state that a person with impaired ankle stability demonstrated a different way of initiating walking strategies than normal people. In other words, such impairement was related to changes in the supraspinal mechanism of motor control. Peterson and Renstrom (2005) state that repeated injuries can cause mechanical and functional ankle instability simultaneously.

Inappropriate injury rehabilitation also has the potential to cause weakness of ankles which may lead to chronic ankle instability (Hubbard and Turner, 2015). Therefore, it is necessary to use a comprehensive functional approach for ankle sprain treatment and rehabilitation with the help of doctors, physiotherapy, or sports massage (Haddad, 2016).

The combination of glute exercise and isometric basic exercise therapies also need to be done to more rapidly improve postural deficits, especially stability disorders caused by ankle sprain. A previous study conducted by Syafrianto et al., (2017) further explains additional glute exercise and basic exercise therapies could increase ankle stability in patients with chronic ankle sprain a p-value of 0.001 . It indicates there was a significant difference between the administration of isometric basic training and additional glute exercise beside an isometric basic exercise therapy.

When a person with chronic ankle instability fails to improve his ankle condition through conservative management and physical exercise therapy, surgery is the only option to cure the pain. Before taking surgery, pepopel with ankle sprain should try non-surgical treatment for at least the first 2 months (Al-Mohrej and Nader, 2016). Surgical treatment for ankle sprain is very rare. It will only be performed if the ankles do not improve and experience persistent ankle instability after undergoing months of RICE and non-surgical alternatives. Two surgical options can be done depending on the severity of the injury, arthroscopy, and reconstruction. Almost all ankle sprain can be treated without surgery. Even complete ligament tears can heal without surgical treatment if treated properly. Minor injury management usually takes about 2 weeks, while more severe injurie management takes 6-12 weeks. People with ankle sprain status may return to sports activities if they have passed recovery phases and feel no pain in joint motion, no more swelling, better muscle capacity, improved ankle flexibility and proprioceys, improved cardiovascular endurance, no biomechanical abnormalities, and better psychological condition (Haddad, 2016).

\section{CONCLUSION}

In conclusion, this study addresses a history of ankle sprain $(\mathrm{p}=0.002)$ and ankle stability $(\mathrm{p}=0.013)$ had $\mathrm{a}$ relationship with ankle sprain status in basketball athletes at Universitas Airlangga, Surabaya. Athletes with injury history had a 9 times greater risk for having ankle sprain again than those without such injury history. Athletes with poor ankle stability were 6 times at more risk for ankle sprain compared to those with good ankle stability. However, gender 
was not related to ankle sprain status in the basketball athletes $(\mathrm{p}=0.435)$.

To have better recovery, athletes should pay more attention on ankle sprain treatment and rehabilitation. Athletes also could improve ankle stability by doing balance exercises including glute exercise and isometric basic exercise therapies to minimize the incidence of ankle sprain. Besides, they are advised to take several other precautions such as practicing movements in a regularly, systematically and programmed manner, doing exercises in a physically and spiritually healthy condition, wearing adequate protectors such as ankle tape or ankle brace, wearing shoes that fit to types of activities performed, warming up and cooling down after and after exercises.

\section{REFERENCE}

Al-Mohrej, O.. and Nader, S.., 2016. Chronic Ankle Instability: Current Perspectives. Avicenna J Med, 6(4), pp.103-108.

Barr, K.. and Harrast, M., 2005. EvidenceBased Treatment of Foot and Ankle Injuries in Runners. Physical Medicine and Rehabilitation Clinics of North America, 16(3), pp.779-799.

Baumbach, S.F., Fasser, M., Polzer, H., Sieb, M., Regauer, M., Mutschler, W., Schieker, M. and Blauth, M., 2013. Study Protocol: The Effect of Whole Body Vibration on Acute Unilateral Unstable Lateral Ankle Sprain-A Biphasic Randomized Controlled Trial. BMC Musculoskelet Disord, 14(22), pp.1-9.

Beynnon, B.D., Murphy, D.F. and Alosa, D.M., 2002. Predictive Factors for Lateral Ankle Sprains: A Literature Review. Journal of Athletic Training, 37(4), pp.376-380.

Chan, K., Ding, B. and Mroczek, K., 2011. Acute and Chronic Lateral Ankle Instability in the Athlete. Bulletin of the Nyu Hospital for Joint Disease, 69(1), pp.17-26.

Chinn, L. and Hertel, J., 2010. Rehabilitation of Ankle and Foot Injuries in Athletes. Clinical Sports Medicine, 29(1), pp.157-167.

Consumer Product Safety Commission, 2017. National Electronic Injury Surveillance System. United States: Hospital Emergency Department.

Deun, S.V., Filip, F.S. and Karel, H.S., 2007. Relationship of Chronic Ankle Instability to Muscle Activation Patterns During the Transition from Double-Leg to Single-Leg Stance. The American Journal of Sports Medicine, 35(2), pp.274-281.

Ericksen, H. and Gribble, P., 2012. Sex Differences, Hormone Fluctuations, Ankle Stability, and Dynamic Postural Control. Journal of Athletic Training, 47(2), pp.143148.

Feger, M.. and Luke, D., 2014. Lower Extremity Muscle Activation During Functional Exercises in Patients with and Without Chronic Ankle Instability. American Academy of Physical Medicine and Rehabilitation, 6, pp.602-611.

Fong, D.T., Hong, Y., Chan, L., Yung, P.S. and Chan, K., 2007. A Systematic Review on Ankle Injury and Ankle Sprain in Sports. Sports Medicine, 37(1), p.73094.

Giriwijoyo, S., 2017. Fisiologi Kerja dan Olahraga: Fungsi Tubuh Manusia Pada Kerja dan Olahraga. Depok: PT. Raja Grafindo Persada.

Gordon, A.I., Lindsay, J.D., Craig, R.D. and Rosemary, B.., 2014. College and Professional Women's Basketball Players' Lower Extremity Injuries: A Survey of Career Incidence. International Journal Of Athletic Therapy \& Training, 19(5), pp.25-33.

Halabchi, F., Hooman, A., Maryam, M. and Mohammad, H.P.S. 
Mohammad, A.., 2016. The Prevalence of Selected Intrinsic Risk Factors for Ankle Sprain Among Elite Football and Basketball Players. Asian J Sports Med, 7(3), p.e35287.

Hoch, M.C., Mullineaux, D.R., Jeon, K. and McKeon, P.O., 2016. Sagittal Plane Gait Kinematics in Individuals with Chronic Ankle Instability. International Journal of Athletic Therapy \& Training, 21(5), pp.28-35.

Hubbard, T.T. and Turner, M.J., 2015. Physical Activity Levels in College Students with Chronic Ankle Instability. Journal of Athletic Training, 50(7), pp.742-747.

Indonesian Ministry of Health, 2007. Laporan Riset Kesehatan Dasar (Riskesdas) Tahun 2007. Jakarta: Indonesian Ministry of Health.

Indonesian Ministry of Health, 2013. Laporan Riset Kesehatan Dasar (Riskesdas) Tahun 2013. Jakarta: Indonesian Ministry of Health.

Indonesian Ministy of Youth and Sports, 2015. Media Informasi Rumah Sakit Olahraga Nasional. Jakarta: Indonesian Ministry of Youth and Sports.

Ito, E., Iwamoto, J., Azuma, K. and Matsumoto, H., 2015. Sex-Specific Differences in Injury Types among Basketball Players. Journal of Sports Medicine, 6(1), pp.1-6.

Kobayashi, T., Masashi, T. and Masahiro, S., 2016. Intrinsic Risk Factors of Lateral Ankle Sprain: A Systematic Review and Meta-Analysis. Sports Health, 8(2), pp.190-193.

Mann, G. and Meir, N., 2002. The Unstable Ankle. United States: Human Kinetics.

Martin, R.., 2003. The Development of Foot and Ankle Ability Measure. Pittsburgh: University of Pittsburgh.

McHugh, M.P., Timothy, F.T., Danielle, T.T., Michael, J.M. and J.N., S.,
2006. Risk Factors for Noncontact Ankle Sprains in High School Athletes. The American Journal of Sports Medicine, 34(3), pp.464470.

McKay, G.D., Goldie, P.A., Payne, W.R. and Oakes, B.W., 2001. Ankle Injuries in Basketball: Injury Rate and Risk Factors. British Journal Sport Medicine, 35, pp.103-108.

National Institute of Arthritis and Musculoskeletal and Skin Disease, 2004. Sport Injuries. Bethesda: National Institute of Health.

O'Connor, F.G., Sallis, R., Wilder, R., Pierre, P. St. and O'COnnor, F., 2004. Sports Medicine: Justs the Facts. United States: McGraw-Hill.

Peterson, L. and Renstrom, P., 2005. Sports Injuries Their Prevention and Treatment. 3rd ed. Gillingham, Kent: Taylor \& Francis e-Library.

Sankey, R.A., Brooks, J.H.M., Kemp, S.P.T. and Haddad, R.S., 2008. The Epidemiology of Ankle Injuries in Professional Rugby Union Players. The American Journal of Sports Medicine, 36(12), pp.2415-2424.

Sarwack, J.F. and Chyntia, R.L., 2014. Pediatric Orthopaedics and Sport Injuries : A Quick Reference Guide. 2nd ed. Elk Grove Village: American Academy of Pediatrics.

Sitepu, I.D., 2018. Manfaat Permainan Bola Basket Untuk Anak Usia Dini. Jurnal Prestasi, 2(3), pp.27-33.

Syafrianto, D., Nyoman, M.., Indra, L., Ida, B.N., I Wayan, W. and Ali, I., 2017. Penambahan Glute Exercise Pada Terapi Latihan Dasar Lebih Meningkatkan Stabilitas Ankle pada Penderita Sprain Ankle Kronis. Sport and Fitness Journal, 5(2), pp.51-57.

Trojian, T.H. and McKeag, D.B., 2006. Single Leg Balance Test to Identify Risk of Ankle Sprains. Br J Sports Med, 40(7), pp.610-613.

Tummala, S.V., David, E.H., Justin, L.M., Karan, A.P., MD and Chhabra, A., 
2018. 10-Year Epidemiology of Ankle Injuries in Men's and Women's Collegiate Basketball. The Orthopaedic Journal of Sports Medicine, 6(11), pp.1-9.

Walden, M., Hagglund, M. and Ekstrad, J., 2005. UEFA Champions League Study: A Prospective Study Of Injuries in Professional Football During The 2001-2002 Season. British Journal of Sports Medicine, 39, pp.543-546.

Waterman, B.R., Brett, D.O., Shaunette,
D., Michael, A.Z. and Philip, J.B., 2010. The Epidemiology of Ankle Sprains in the United States. The Journal of Bone and Joint Surgery, 92(22), pp.79-84.

Wikstrom, E.A., Hubbard-Turner, T. and McKeon, P.O., 2013. Understanding and Treating Lateral Ankle Sprains and Their Consequences: A ConstraintsBased Approach. Sports Medicine, 43(6), pp.385-393. 